\title{
FATIGUE STRENGTHS OF BOX SECTION TRUSS CHORD WITH CORNER JOINTS
}

\author{
By Koei TAKENA*, Shigeru HIRANO*, Fumio ITOH** \\ and Chitoshi MIKI***
}

\begin{abstract}
Box section specimens of various types of corner joints were fatigue tested under axial loading condition by using a $4 \mathrm{MN}$ fatigue testing machine. The specimens were fabricated by commonly used and newly developed welding processes. The fatigue strengths of joint and behaviors of fatigue crack propagation from various kinds of weld defects in corner joints are described. Influences of weld defects on the fatigue strengths of joints and permissible blowhole size in actual truss chord members are examined.

Keywords: fatigue strength, truss chord, corner joint, defect
\end{abstract}

\section{FOREWORD}

Corner joints with partially penetrated welds are often used to build box section truss chord members. Hence, in the design of truss chord members, fatigue strength of the partially penetrated longitudinal welded joint is important and it may ultimately determine the member's cross section. For this reason, the Honshu-Shikoku Bridge Authority performed fatigue tests using large specimens with longitudinal welds ${ }^{1)}$ and truss structures in order to examine the fatigue strength of truss chord members of high tensile steels ${ }^{2}$. In the tests of these truss structures, weld defects, such as blowholes originating at the weld root, resulted in a much lower fatigue strength than the design fatigue allowable stress for A-class joints for steel railway bridges ${ }^{3)}$. Therefore, the Authority studied the causes of weld defects and the conditions under which weld defects may develop in corner joints. As a result of this research, various new welding methods were proposed to prevent weld defects during bridge fabrication.

This paper summarizes the results of studies of fatigue strengths of corner welds which were performed by the Honshu-Shikoku Bridge Authority. The fatigue tests were carried out on box cross section specimens with partially penetrated welds and fillet welds. Specimens were welded by various methods including commonly used and newly developed welding processes.

\section{TEST METHOD}

\section{(1) Specimens}

The configurations and dimensions of the specimens are shown in Fig. 1. The chemical composition and

* Member of JSCE, Honshu Shikoku Bridge Authority (Mori Bld. No. 22, Toranomon, Minato-ku, Tokyo, 105)

** Member of JSCE, Japan Construction Method and Machinary Research Institute (Fuji, Shizuoka, 417)

*** Member of JSCE, Dr. of Eng., Assoc. Prof., Tokyo Institute of Technology (Meguro-ku Tokyo. 152) 
mechanical properties of the steel are shown in Table 1. The cross section of each specimen has a box shape of $300 \mathrm{~mm} \times 130 \mathrm{~mm}$, contains a parallel section $1 \mathrm{~m}$ long and uses $800 \mathrm{MPa}$ class steels. Pin-plates for mounting a test machine, $50 \mathrm{~mm}$ thick and made of SM 58 steel, were attached at both ends of the box specimen. Four different types of specimens were employed for the corner welds of chords : BB, which has conventional, partially penetrated groove welds $; \mathrm{BD}$ and $\mathrm{BE}$, which are more developed versions of $\mathrm{BB}$; and $\mathrm{BF}$, which has fillet welds. Welding conditions for each specimen are shown in Table 2. In fabricating specimens $\mathrm{BD}, \mathrm{BE}$ and $\mathrm{BF}$, the root-gap was kept under $0.5 \mathrm{~mm}$ in order to prevent uneven penetration lines. In order to minimize the occurrence of weld defects, special treatments were applied on the stop and start positions of tack welding beads, the grooves were kept clean, and a stabilized electric source was utilized. The BB-type specimens were welded with a commonly used submerged arc welding process and the $\mathrm{BD}$-type specimens were made into $\mathrm{J}$-shaped grooves to facilitate positioning of the electrode and in order to get deep penetration. Welding was done by using the MIG welding process which prevents the slag inclusion caused by flux. Stop and start positions of tack welds were smoothed by a grinder.

The BE-type specimen is similar to the BB-type with $50^{\circ}$ single bevel grooves. The tandem submerged arc welding process was employed for the $\mathrm{BE}$-type specimen. The welding process was such that the second electrode of the tandem submerged arc welding system was put the additional weld metal before the weld metal by the first electrode became solidified. This tandem electrode system provides deep weld penetration and prevents the development of weld cracks. Seal welding was performed on the tack welds beads and the surface of the weld was made smooth; the root position was kept dust-free, and the groove was kept clean.

The BF-type specimen was fillet-welded and yielded the best results for chord member corner weld joints. These specimens had fewer weld defects in comparison with partially penetrated groove welds. One-electrode, submerged arc welding was used, and as in the case of $\mathrm{BD}$, both ends of the tack welds beads were smoothed by a grinder.

\section{(2) Measurement of Residual Stress}

Welding residual stress, which is considered to influence the fatigue strength of chord members with corner welds, was measured by the cutting procedure. Two types of specimens were used : (1) BB-1, measured after fatigue tests and (2) a BC-type specimen with a $1 \mathrm{~m}$ parallel weld region not subjected to fatigue tests. Both specimens had the same type of corner welds. For the measurement, $3 \mathrm{~mm}$ long, waterproof, three axial gauges were attached on both inside and outside surfaces of the box. The final free distortion was measured after the specimens were cut into small pieces of about 35 long $\times 20$ wide $\times 15$ thick (mm) with a saw.

\section{(3) Performance in Fatigue Tests}

Fatigue tests were performed using a servo-controlled fatigue testing machine with $4 \mathrm{MN}$ dynamic
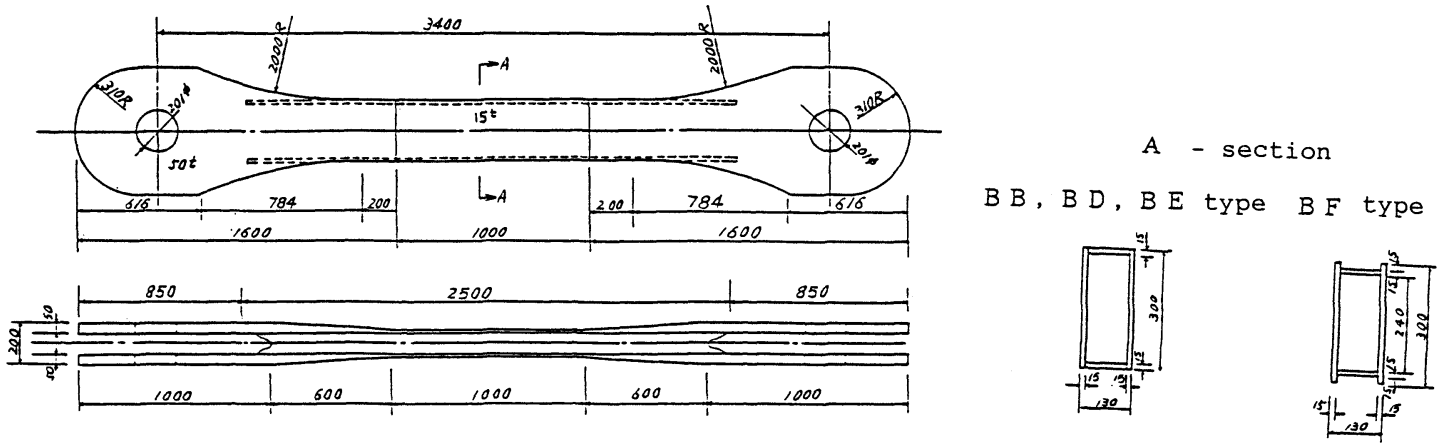

Fig. 1 Configurations and Dimensions of the Specimen. 
Table 1 Mechanical Properties and Chemical Composition of $800 \mathrm{MPa}$ Class Steels Tested.

\begin{tabular}{|c|c|c|c|c|c|c|c|c|c|c|c|c|c|}
\hline \multicolumn{3}{|c|}{ Mechanical Properties } & \multicolumn{10}{|c|}{ Chemical Composition( $(z)$} & \multirow{2}{*}{ SPECTMEN } \\
\hline $\begin{array}{r}\mathrm{Y} . \mathrm{S} \\
\mathrm{N} / \mathrm{mm}^{2} \\
\end{array}$ & $\begin{array}{r}\text { T.S. } \\
\mathrm{N} / \mathrm{mm}^{2} \\
\end{array}$ & $\begin{array}{c}\text { El. } \\
8\end{array}$ & c & $\begin{array}{r}\mathrm{Si} \\
\times 10 \\
\end{array}$ & Mn & $\begin{array}{l}\mathbf{P} \\
\times 1 \\
\end{array}$ & $\mathbf{s}$ & $\mathrm{Cu}$ & $\begin{array}{l}\mathrm{Ni} \\
0\end{array}$ & $\mathrm{Cr}$ & Mo & $\begin{array}{c}\mathrm{V} \\
1000 \\
\end{array}$ & \\
\hline 833 & 882 & 29 & 11 & 26 & 97 & 18 & 8 & 26 & 8 & 53 & 39 & 44 & $\mathrm{BB}$ \\
\hline 744 & 843 & 26 & 12 & 24 & 94 & 12 & 4 & 23 & 94 & 52 & 33 & 40 & $\mathrm{BD}, \mathrm{BE}, \mathrm{BF}$ \\
\hline
\end{tabular}

Table 2 Welding Conditions.

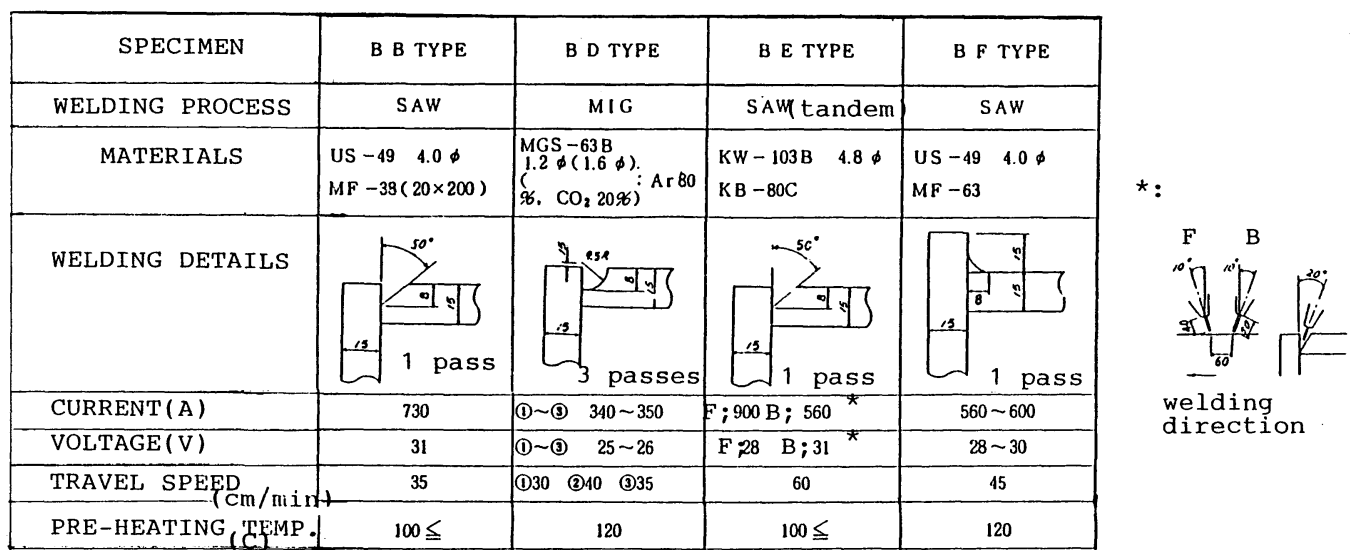

capacity. Repetition rate of the tests was $120-300 \mathrm{cpm}$. Minimum load was set at $5 \mathrm{KN}$. In order to observe the initiation and growth behaviors of fatigue cracks, minimum stress was increased while maximum stress was maintained and the stress range was halved every $\mathrm{X}$ number of cycles; this formed beach marks on the failure surface. A $40 \times$ microscope was used for observation of beach marks and blowholes.

\section{RESIDUAL STRESS DISTRIBUTIONS}

The residual stresses measured on the surfaces inside and outside the box are shown in Fig. 2. Residual stresses on the inside and outside surfaces of the box are nearly the same. The maximum tensile residual stress, $420-470 \mathrm{~N} / \mathrm{mm}$, was measured on the beads in the $\mathrm{BC}$ specimen. After the fatigue tests, the

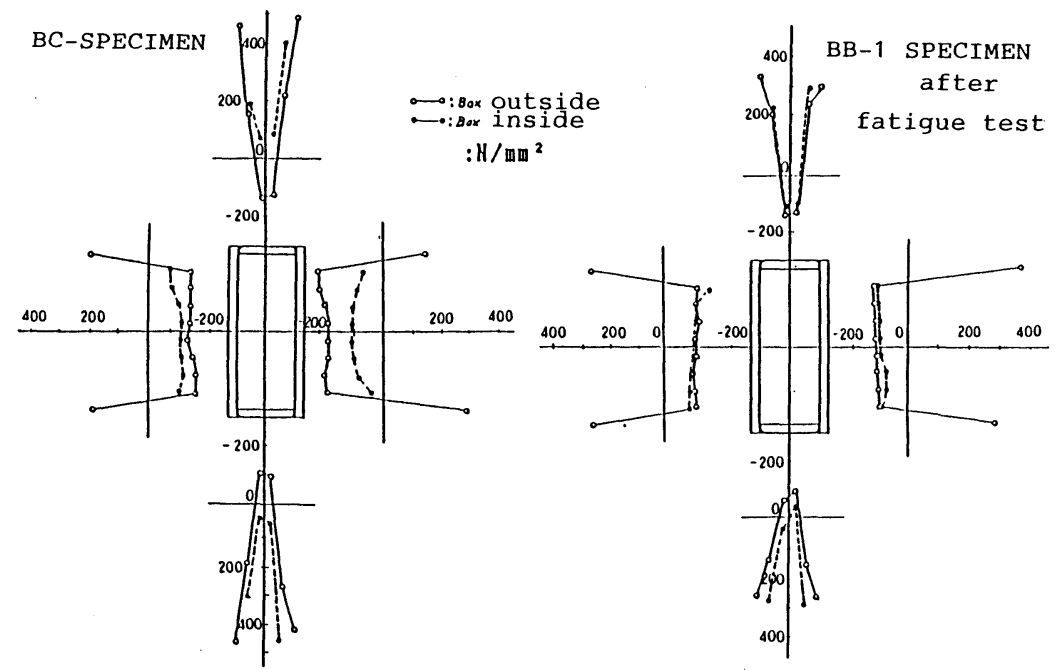

Fig. 2 Measured Residual Stress Distributions. 
residual stress decreased more in BB-1 than in BC. A high tensile residual stress of $255-360 \mathrm{~N} / \mathrm{mm}^{2}$ was observed on and near the weld beads. The yield strength of the welded metal cut from $\mathrm{BC}$ was approximately $540 \mathrm{~N} / \mathrm{mm}^{2}$; the fatigue test stress was $167 \mathrm{~N} / \mathrm{mm}^{2}$. The lowering of the residual stress is considered to have been caused by redistribution of the stress created by yielding in the region of the weld beads.

\section{RESULTS OF FATIGUE TESTS}

\section{(1) Fatigue Strength}

The results of the fatigue tests are shown in Table 3. The number of cycles during the half-stress range which left beach marks is not included in the failure life, $N_{f}$. Photos 1 to 7 are typical fatigue failure surfaces of corner welds. Fig. 3-5 show the relationship between stress ranges, $\mathrm{S}$, and failure life, $N_{f}$, and regression lines for these results calculated by the least mean squares method. The following test specimens were excluded from these regression analyses : the results of a $T$-type specimen ${ }^{1)}$ that failed because of a repair welding defect in the base plate, and BF-1 and BF- 3 specimens that failed because of a defect caused by an error in the welding of tub plates to butt joints.

Fig. 3 summarizes all the test results of large-sized, longitudinally-welded joint specimens and box specimens with a confidence of $5 \%, 50 \%$ and $95 \%$ for survival for the truss specimens reported in the previous paper $^{2)}$. For comparison, the B class design life curve ${ }^{4)}$ is also shown. Fatigue strength increased in the following order: truss specimens, box BB type specimens, box specimens welded by the improved method (BD, BE and BF type), and plate T-specimens. Failures in truss and BB specimens were caused by fatigue cracks which occurred in the region of the root. Among BD, BE, BF and T specimens, failures were caused by fatigue cracks which initiated at the weld bead surface. This indicated that fatigue strength could be increased by minimizing weld defects (mainly blowholes) in the root area, and, that weld defects on the weld bead surface can be enhanced. Therefore, fatigue strength of the joint was analyzed in two different ways : (1) situations where fatigue cracks were initiated in the root area and (2) situations where cracks initially developed on the weld bead surface.

Fig. 4 summarizes the test results of specimens whose failure in Fig. 3 was caused by fatigue cracks which initiated in the root area. As indicated later in section 5 , the size of the blowholes diminishes in the following order : truss specimens, $\mathrm{BB}$ specimens, specimens welded with the improved method $(\mathrm{BD}, \mathrm{BE}$ and $\mathrm{BF}$ ), and $\mathrm{T}$ specimens, and the fatigue strength increases in the same order. This supports the conclusion that fatigue strength increases as the blowholes become smaller ${ }^{6}$. The fatigue strength of specimens welded with the improved welding method satisfies A-class joint requirements at the lowest limit. The fatigue strengths of $\mathrm{T}$-specimens are higher despite the fact that these blowholes are nearly the same size as those of $\mathrm{BE}$ type specimens, with a shape similar to those of an actual structure. These

Table 3 Fatigue Test Results.

\begin{tabular}{|c|c|c|c|c|c|}
\hline \multirow[b]{2}{*}{ SPECIMEN } & \multirow[b]{2}{*}{$\begin{array}{l}\text { STRESS RANGE } \\
\mathrm{N} / \mathrm{mm}^{2}\end{array}$} & \multirow[b]{2}{*}{$\begin{array}{c}\text { FAILURE LIFE } \\
\times 10^{3} \text { cycles } \\
\end{array}$} & \multicolumn{2}{|c|}{ BEACH MARK TEST } & \multirow[b]{2}{*}{ CAUSE OF FATIGUE CRACK } \\
\hline & & & \begin{tabular}{|l|} 
NUMBER OF \\
STRESS BIOCKS \\
\end{tabular} & $\begin{array}{l}\text { NUMBEER OF } \\
\text { BEACH MIARKS }\end{array}$ & \\
\hline $\begin{array}{r}\mathrm{BB}-1 \\
-2 \\
-3\end{array}$ & $\begin{array}{l}171 \\
146 \\
124\end{array}$ & $\begin{array}{l}1196 \\
1992 \\
3000 \star \star\end{array}$ & $\begin{array}{l}9 \\
5\end{array}$ & $\begin{array}{l}9 \\
5\end{array}$ & $\begin{aligned} \text { blowhole at weld-root, } & 2.5 \times 1.8 \mathrm{~mm}^{\star} \\
& 4.1 \times 3.4 \mathrm{~mm}^{\star}\end{aligned}$ \\
\hline $\begin{array}{r}\mathrm{BD}-1 \\
-2 \\
-3\end{array}$ & $\begin{array}{l}223 \\
194 \\
165\end{array}$ & $\begin{array}{l}1043 \\
1078 \\
1940\end{array}$ & $\begin{array}{l}5 \\
8\end{array}$ & $\begin{array}{l}5 \\
8\end{array}$ & $\begin{array}{l}\text { irregularity on weld-bead surface } \\
\text { blowhole at weld-root, } 2.6 \times 3.9 \mathrm{~mm}{ }^{\star} \\
\text { weld defect near surface, } 1.2 \times 0.6 \mathrm{~mm}^{*}\end{array}$ \\
\hline $\begin{array}{r}\mathrm{BE}-1 \\
-2 \\
-3\end{array}$ & $\begin{array}{l}215 \\
188 \\
160\end{array}$ & $\begin{array}{l}1005 \\
1279 \\
2187\end{array}$ & 19 & 12 & $\begin{array}{l}\text { weld-root } \\
\text { blowhole at weld-root, } \begin{array}{l}1.1 \times 0.5 \mathrm{~mm}^{*} \\
1.4 \times 0.7 \mathrm{~mm}^{*}\end{array}\end{array}$ \\
\hline $\begin{array}{r}\mathrm{BF}-1 \\
-2 \\
-3 \\
-4\end{array}$ & $\begin{array}{l}198 \\
194 \\
194 \\
165\end{array}$ & $\begin{array}{r}807 \\
1350 \\
740 \\
3150 \\
\end{array}$ & $\begin{array}{r}15 \\
5\end{array}$ & $\begin{array}{l}8 \\
5\end{array}$ & $\begin{array}{l}\text { slag inclusion in tab piece welding } \\
\text { weld defect on weld-bead surface } \\
\text { slag inclusion in tab piece welding } \\
\text { weld-root }\end{array}$ \\
\hline
\end{tabular}


results suggest that the fatigue strength of actual structures cannot be simulated in these simplified and idealized plate specimens.

Fig. 5 shows the test results of some specimens from Fig. 3, whose failure was caused by fatigue cracks originating at the weld bead surface. The bending test result on a large-sized truss chord ${ }^{5}$ is also shown in Fig. 5, in which fatigue cracks originated from surface ripples at the stop and re-start points of manual fillet welds. While the fatigue strength of some of these specimens does not satisfy the allowable stress for class-A joints, all of them satisfy that for class-B joints. Therefore, if the improved welding method, which diminishes blowholes at the roots, is used for corner joints, the joints should be categorized into class-B. However, there is a possibility that the fatigue strength of the manually welded joint does not satisfy class-B requirements when significant ripples remain on the surfaces.

(2) Initiation of Fatigue Cracks

Fig. 6 is the histogram of the occurrence of blowholes larger than $0.5 \mathrm{~mm}$ and of fatigue cracks as observed by longitudinal exposing examinations along the weld (Fig. 7). Typical blowholes are shown in photos 8 and 9. As shown in Fig. 6, the larger the size of the blowhole, the higher the occurrence ratio of fatigue cracks. Photo 8 shows a fatigue crack that started from the upper position of the sharp shape of a $1 \mathrm{~mm}$ high blowhole, and Photo 9 shows a situation where, in spite of the height of the $4 \mathrm{~mm}$ blowhole, no fatigue crack occurred because the shape was smooth. These results indicate that longitudinal exposing

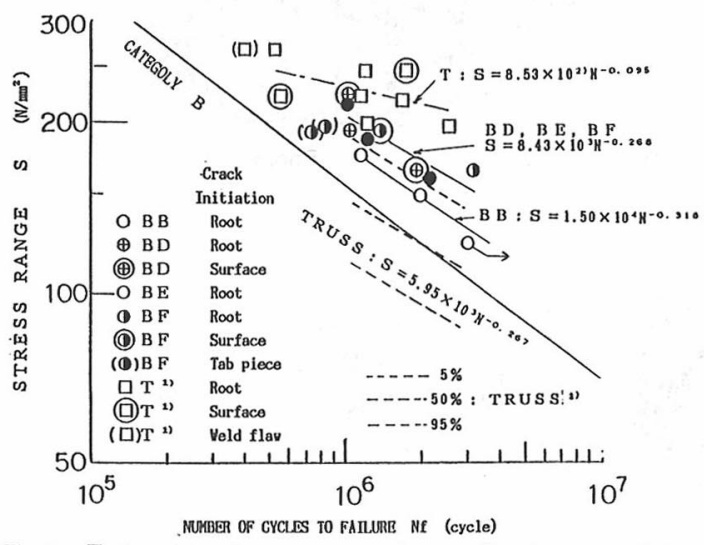

Fig. 3 Fatigue Test Results of Box-Section Specimens and Other Large-Sized Longitudinally Welded Specimens (Truss and Plate type Specimens).

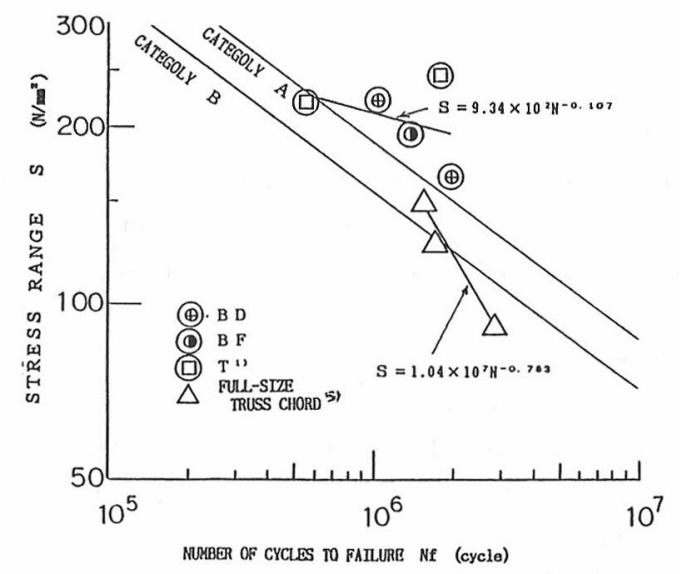

Fig. 5 Fatigue Test Results, Fatigue Cracks Originated on the Weld Bead Surfaces.

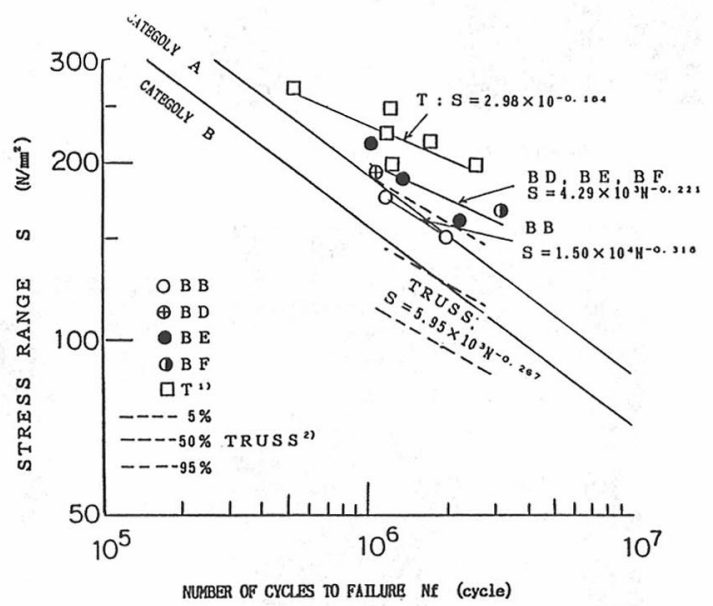

Fig. 4 Fatigue Test Results, Fatigue Cracks Initiated in the Root Area.

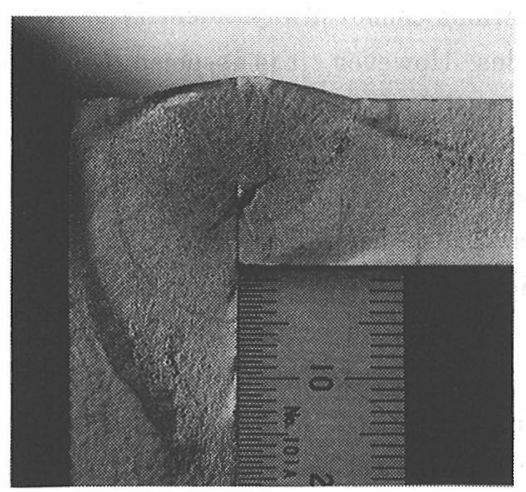

Photo1 BB-1 Specimen. 


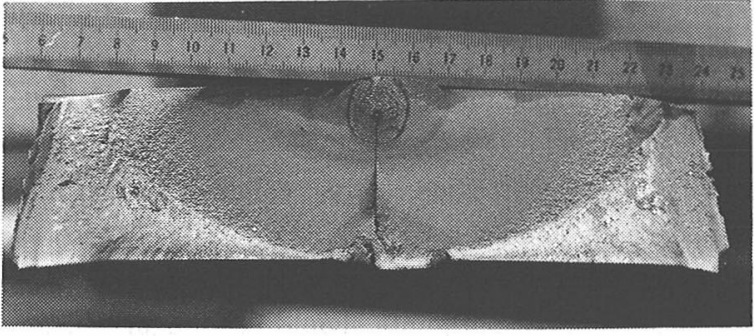

Photo2 T-8 Specimen ${ }^{1)}$, blowhole $0.6 \times 0.4 \mathrm{~mm}$ Failure Surface with Beach Marks $S=216 \mathrm{MPa}, N_{f}=1708 \times 10^{3}$.

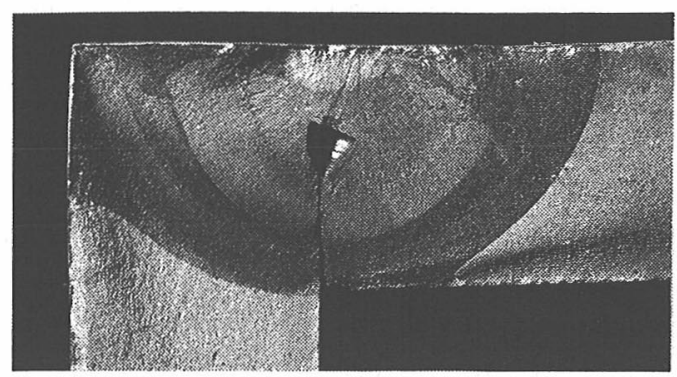

Photo 3 D-1 Truss Specimen ${ }^{2)}, S=1520 \mathrm{MPa}$, $N_{c}=1405 \times 10^{3}$.

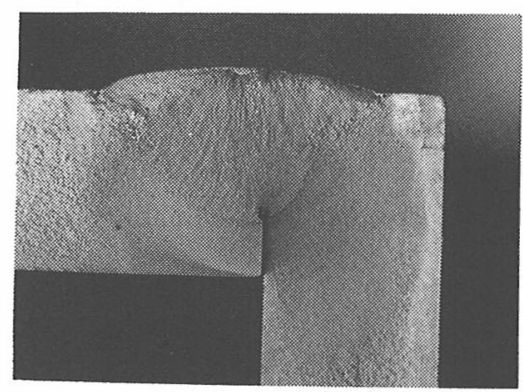

Photo 4 BE-3 Specimen.

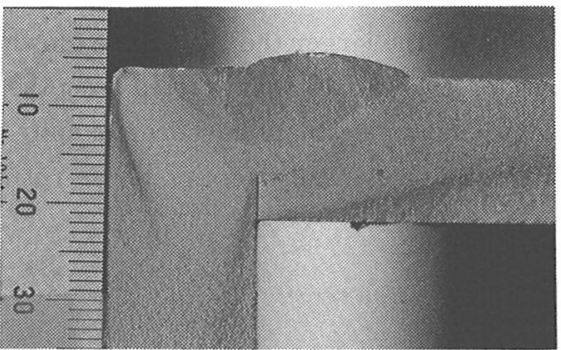

Photo5 BD-3 Specimen.

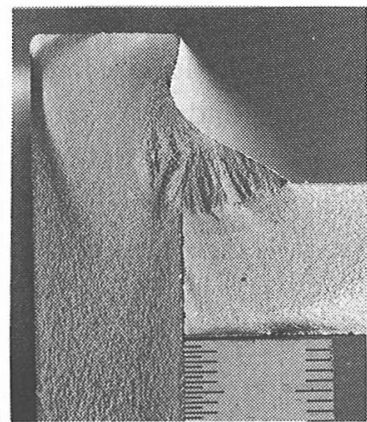

Photo 6 BF-2 Specimen.
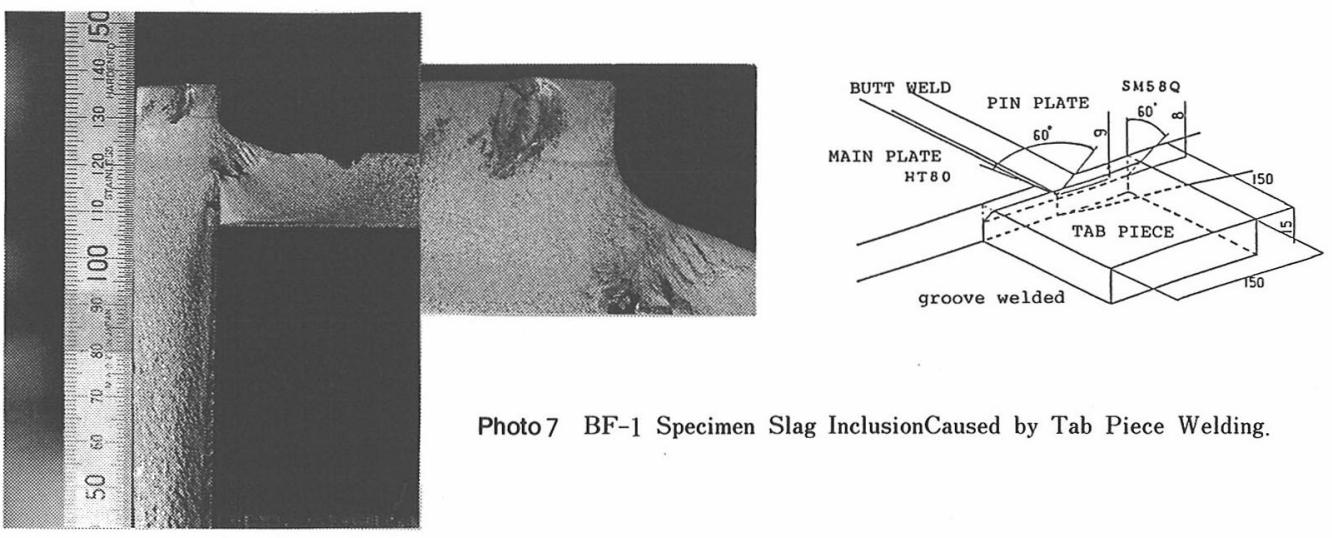

Photo7 BF-1 Specimen Slag InclusionCaused by Tab Piece Welding.

examinations cannot always identify starting points of fatigue cracks or discover the highest position of blowholes. However, it is assumed that the occurrence of fatigue cracks is influenced not only by the size but by the shape as well. Although $\mathrm{BD}, \mathrm{BE}$, and $\mathrm{BF}$ were very carefully fabricated, as shown in Table 2, quite a few blowholes still existed. It is difficult to prevent the initiation of blowholes with the current welding techniques.

Other causes of fatigue cracks were unevenness along the weld bead surface in BD-1, and slag inclusions, which were confirmed by analysis by Electron Probe Micro-Aralyzer (EPMA) in BD-3 and $\mathrm{BF}-3 . \mathrm{BF}$ has a tab-piece, attached, as shown in Photo 7, to the butt weld of the main plate. In BF-1 and $\mathrm{BF}-3$, defects occurred in the attached portion of the tab piece at the end of the plate, cracks developed and failure resulted (Photo 7). Observation by Scanning Electron Microscope (SEM) and results of an EPMA element analysis show that the causes of fatigue were blowholes in $\mathrm{BF}-1$ and slag inclusions in $\mathrm{BF}-3$. 


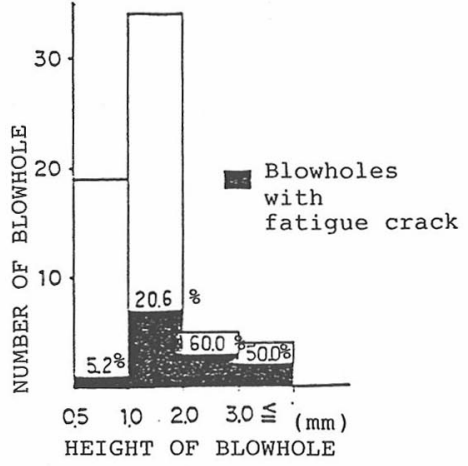

Fig. 6 Occurrence of Blowholes and of Fatigue Cracks.

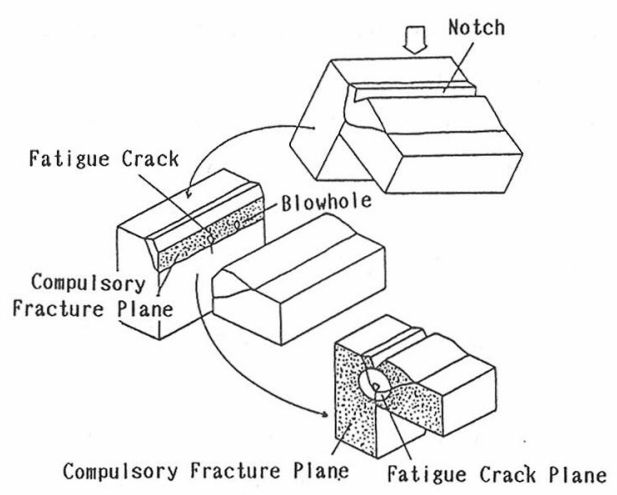

Fig. 7 Longitudinal Exposing Examination.
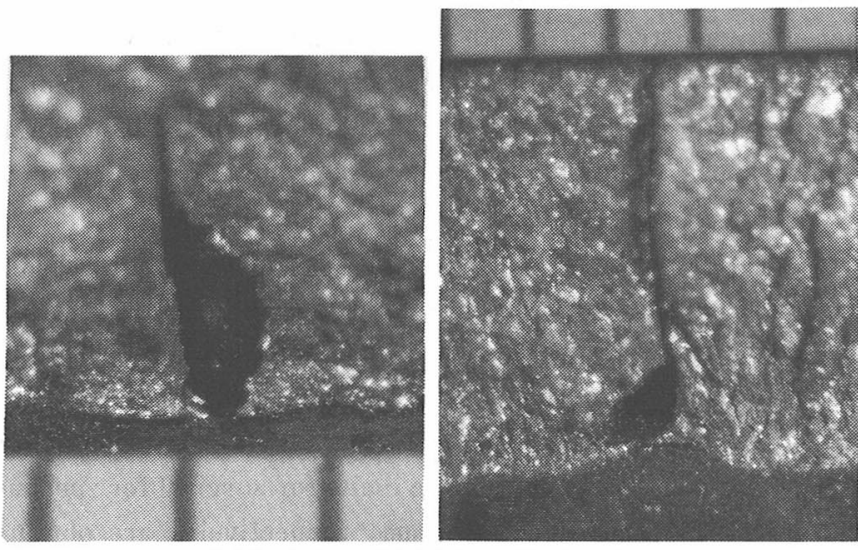

Photo 8 Small Blowholes with Fatigue Cracks (BD-1 Specimen).

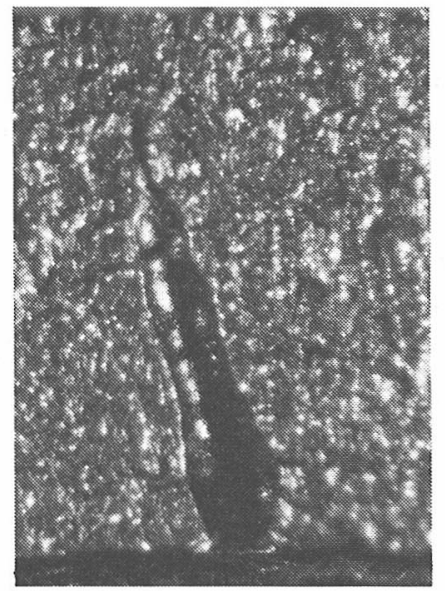

Photo9 Large Blowhole without Fatigue Crack (BB-1 Specimen).

\section{RELATIONSHIP BETWEEN FATIGUE STRENGTH AND SIZE OF BLOWHOLE}

\section{(1) Fatigue Strength at 2 million cycles}

As shown in Table 3, the number of stress blocks and the number of beach marks agree in specimens which failed due to fatigue cracks from blowholes. This indicates that the fatigue cracks initiated in the early stages of fatigue tests, before the first halving of stress amplitude. Beach marks on the failure surface indicate that multiple numbers of fatigue cracks originated simultaneously on the surface of the blowhole and grew, with coalescing. The pattern of cracks is complicated in the early stages of crack propagation and it is difficult to calculate the exact stress intensity factors for these cracks. Therefore, imaginary initial disk shapes with radius $a_{i}$, which provide the same fatigue-life test results when tested by fracture mechanics analysis, were considered and the 2 million fatigue strength was obtained. Assumptions used in this analysis are as follows:

(i) Fatigue cracks start at the weld root and proceed radially. Therefore, the following stress intensity factor was used ${ }^{6.7)}$ (refer to Fig. 9) :

$$
K=s \sqrt{\pi a} \cdot \frac{2}{\pi} \cdot \sqrt{\frac{\sec (\pi \lambda)}{2}} \cdot \sqrt{\frac{\sec 2(\lambda \varepsilon)}{2 \lambda \varepsilon}}
$$
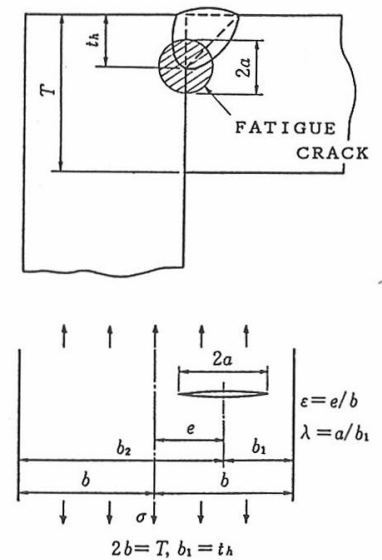

Fig. 9 Fatigue Crack Model. 
(ii) The final crack with radius $a_{f}$ is defined as 0.9 times the distance from the root to the surface (throat thickness).

(iii) The relationship between the stress intensity factor range and the crack propagation rate can be represented by the following equation, and the influence of residual tensile stress is taken into account in this relationship ${ }^{8)}$.

$$
\begin{aligned}
\frac{d a}{d N}= & 5.47 \times 10^{-9}\left(\Delta K^{3}-2.5^{3}\right) \\
& \frac{d a}{d N}: \mathrm{mm} / \mathrm{cyde}, \Delta K: \operatorname{MPa} \sqrt{m}
\end{aligned}
$$

\section{(2) Relationship between size of blowhole and fatigue strength}

Figs. 10 and 11 show the relationship between fatigue strengths at 2 million cycles, $S_{200}$, calculated by the above procedure for specimens whose cracks started at the weld root and the areas of blowhole, $A_{b}$, on the fatigue failure surfaces and the radius of the inscribed circles of the blowhole, $a_{i n}$. These figures show that as the blowhole size increases, fatigue strength decreases. However, the fatigue strength varies for specimens whose blowhole areas and radii are less than $1 \mathrm{~mm}^{2}$ and $0.4 \mathrm{~mm}$, respectively. Photo 4 shows the failure surface of BE-1. In this specimen, fatigue strength $S 200$ is $180 \mathrm{~N} / \mathrm{mm}^{2}$ and this value is low although there is no blowhole (Figs. 10 and 11). Compared with this and T-type specimens, simplified plate specimens have high fatigue strengths in spite of their small blowholes. This can be explained in that as the size of the blowhole decreases, the unevenness of the weld root due to the variability of penetration has some effect.

The permissible size of blowholes for Honshu-Shikoku bridges is determined by the following reasons :

(1) The fatigue strengths of corner joint depends on the size of blowholes.

(2) The difficulty in preventing blowhole initiation with currently available welding techniques.

(3) The difficulty in detecting them, with sufficient accuracy, by non-destructive tests.

The following calculation method was employed : by taking $A_{b}$ and $a_{i n}$ as statistical variables and assuming $\mathrm{S}_{200}$ has a normal distribution, $5 \%, 50 \%$, and $95 \%$ confidence limits for survival for specimens whose blowholes areas and radii, are greater than $1 \mathrm{~mm}^{2}$ and a $0.4 \mathrm{~mm}$, respectively, are obtained. (Figs. 10 and 11). As shown in the figures, the correlation coefficients of fatigue strength, $\mathrm{S}_{200}$, for $A_{b}$ and $a_{i n}$, which represent the size of blowholes, are similar to each other and they are also close to unity. The blowhole sizes of a $95 \%$ confidence limit for survival for the class $\mathrm{B}$ allowable stress range $\left(124 \mathrm{~N} / \mathrm{mm}^{2}\right)$ are $4.6 \mathrm{~mm}^{2}$ and $0.83 \mathrm{~mm}$, respectively. Thus, this is to be considered the size permissible for a blowhole in a structural member whose cracks do not reach the plate surface within their lifetimes. However, it is uneconomical to require this permissible blowhole size for all truss chord members whose

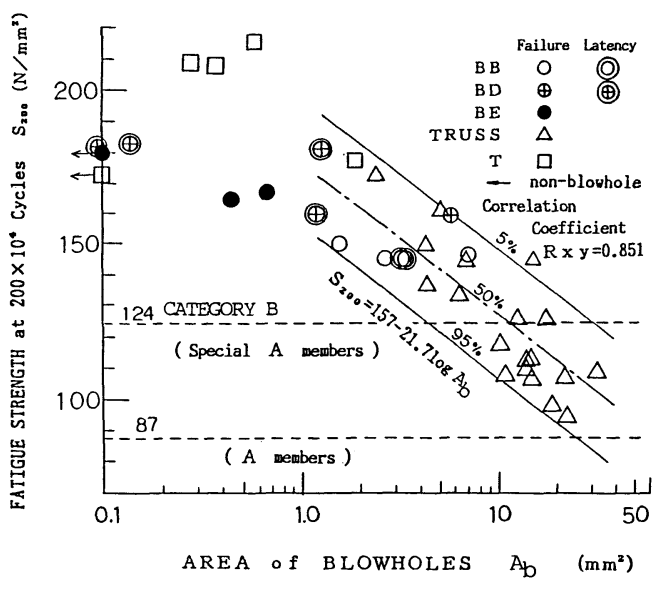

Fig. 10 Fatigue Strength and Blowhole Area.

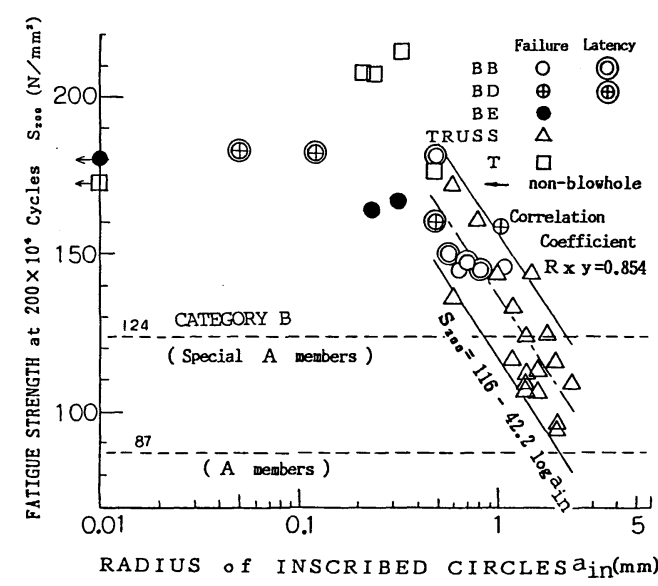

Fig. 11 Fatigue Strength and Blowhole Radius. 
Table 4 Permissible Blowhole Size in the Fabrication of Honshu Shikoku Bridges ${ }^{9}$.

\begin{tabular}{r|c|c}
\hline MEMBER CATEGORY & $\begin{array}{c}\text { PERMISSIBLE BLOWHOLE SIZE } \\
\text { (diameter of inscribed circle) }\end{array}$ & INSPECTION by ULTRA SONIC \\
\hline Special $A, \leqslant 0.7 \mathrm{~S}_{\mathrm{r}} / \mathrm{s}_{\mathrm{a}}$ & $\mathrm{d} \leqq 1.5 \mathrm{~mm}$ & all corner joints \\
$\mathrm{A}, 0.5 \leq \mathrm{S}_{\mathrm{r}} / \mathrm{s}_{\mathrm{a}}<0.7$ & $\mathrm{~d} \leqq 3.0 \mathrm{~mm}$ & all corner joints \\
$\mathrm{B}, \quad \mathrm{S}_{\mathrm{r}} / \mathrm{s}_{\mathrm{a}}<0.5$ & & 208 of corner joints \\
\hline
\end{tabular}

stress ranges are greatly varied : the stress ranges of some members are very low. In the fabrication of Honshu-Shikoku bridges ${ }^{9}$, based on the ratio between the stress range and allowable stress range, members were classified into 3 categories : special A, A, and B, as shown in Table 4. The technological capability of non-destructive testing is also taken into account in this clause. Based on this, defect sizes were set, non-destructive tests were carried out, and members with defects exceeding the allowable values were repaired.

\section{CONCLUSIONS}

(1) In partially penetrated corner joints which are automatically welded, blowholes can be made smaller by improving the welding method. Thus, fatigue cracks are caused by other welding defects which are mostly on the weld bead surface. In general, the fatigue strengths of joints which include these defects satisfy the B-class design allowable stress range.

(2) Even in specimens which are carefully fabricated so as not to create blowholes, there are blowholes. In practical situations, it is very difficult to completely eliminate blowholes in actual structural members using currently available welding techniques.

(3) The correlation between the size of the blowhole as an area or the radius of the inscribed circle and fatigue strength is significant. As the size of blowholes decreases, fatigue strength increases. However, when the size of the blowholes becomes very small, fatigue strength becomes variable due to the unevenness of the surface of the weld bead and of the weld root.

(4) As for the relationship between the 2 million cycles fatigue strength and the areas and the radii of inscribed circles of blowholes, the blowhole area is $4.6 \mathrm{~mm}^{2}$ and the inscribed circle is $0.83 \mathrm{~mm}$ for a $95 \%$ confidence limit for survival under $S_{r}=124 \mathrm{~N} / \mathrm{mm}^{2}$.

\section{ACKNOWLEDGEMENT}

The authors are grateful to Professor Jiro Tajima of Saitama University for his valuable suggestions and coments given for this study.

\section{REFERENCES}

1) Miki, C., Tajima, J., Asahi, K. and Ito, F. : Fatigue Strength of Large-Sized Longitudinal Butt Welds with Partial Penetration, Proc. of JSCE, No. 332, 1982.6.

2) Tajima, J., Takena, K., Miki, C. and Ito. F. : Fatigue Strengths of Truss Made of High Strength Steels, Proc. of JSCE, No. 341, 1984. 1 .

3) Japanese National Railways : Standard Specifications for Railway Bridges, 1973. (in Japanese)

4) Honshu Shikoku Bridge Authority: Specifications for Superstructures, 1983. (in Japanese)

5) Shimokawa, H., Takena, K., Fukazawa, M. and Miki, C. : A Fatigue Test on the Full-Size Truss Chord, Proc. of JSCE, Structural Eng. /Earthquake Eng., I-1, 1984.4.

6) Miki, C., Nishino, F., Hirabayashi, Y. and Ohga, H. : Fatigue Strength of Longitudinal Welded Joints Containing Blowholes, Proc. of JSCE, No. 325, 1982.9.

7) Ishida, M. : Elastic Analysis of Crack and Stress Intensity Factor, Baifukan, 1976.5. (in Japanese)

8) Miki, C., Nishino, F., Hirabayashi, Y. and Takena, K. : Influence of Residual Welding Stress on Fatigue Crack Growth Rate, Proc. of JSCE, No. 330, 1983.2.

9) Honshu Shikoku Bridge Authority: Code for Fabrication of Superstructures, 1977.3. (in Japanese) 